\title{
UPAYA KOMITE SEKOLAH DALAM MENINGKATKAN PRESTASI MADRASAH IBTIDAIYAH MIFTAHUL HUDA KALIBOTO KABUPATEN KEDIRI
}

\author{
Nanik Nur Hidayati \\ MI Miftahul Huda Kaliboto Tarokan Kediri \\ nanikkediri022@gmail.com
}

\begin{abstract}
Abstrak.
Keberhasilan suatu lembaga pendidikan ditentukan oleh hubungan yang baik antara pihak sekolah dengan komite dan antara pihak sekolah dengan masyarakat. Fokus penelitianmeliputi: 1).Keterlibatan Komite Sekolah dalam menentukan kebijakan pendidikan di Madrasah Ibtidaiyah Miftahul Huda Kaliboto, 2).Upaya Komite Sekolah dalam meningkatkan prestasi Madrasah Ibtidaiyah Miftahul Huda Kaliboto Pendekatan yang di gunakan oleh peneliti adalah dengan model kualitatif, yaitu prosedur penelitian yang menghasilkan data deskriptif berupa kata-kata tertulis atau lisan dari orang-orang dan prilaku yang diamati. Metode Penelitian ini menggunakan Metode Kualitatif dengan pendekatan Studi kasus, Penelitian ini mengkaji tentang "Upaya Komite Sekolah dalam Meningkatkan Prestasi Madrasah Ibtidaiyah Miftahul Huda Kaliboto Kabupaten Kediri", data diperoleh melalui dokumentasi, observasi dan wawancara dengan narasumber, kemudian data yang telah diperoleh dilakukan analisa dengan direduksi, dilakukan paparan data dan terakhir penarikan kesimpulan. Hasil penelitian ini menunjukkan bahwa, keterlibatan Komite Sekolah dalam beberapa hal yaitu : a. Memberikan pertimbangan dalam penentuan dan pelaksanaan kebijakan program sekolah, Rencana Anggaran Pendapatan dan Belanja Sekolah, kriteria sarana prasarana sekolah, kerjasama sekolah dengan masyarakat. b. Menggalang dana dan sumber daya pendidikan lainnya dari masyarakat. c. Mengawasi pelayanan pendidikan di sekolah. d. Menindaklanjuti keluhan, saran, kritik, dan aspirasi dari peserta didik, orangtua, dan masyarakat atas kinerja sekolah. Upaya Komite Sekolah bersama kepala sekolah dalam meningkatkan prestasi Madrasah Ibtidaiyah Miftahul Huda Kaliboto: a. Silaturrahim dengan menghadirkan orangtua siswa, pengurus yayasan, pengurus Komite Sekolah dan tokoh-tokoh masyarakat, untuk sarana informasi kependidikan dan perkembangan siswa, b. Silaturrahim antar yayasan, Komite Sekolah, kepala sekolah dan guru setiap tiga bulan sekali, tentang program kerja c. Mengadakan lomba TK dan RA se-Kecamatan Tarokan d. Mengadakan pengajian umum bersama masyarakat di lingkungan Madrasah Ibtidaiyah setiap 2 tahun sekali. e. Untuk peningkatan kompetensi Guru diadakan pelatihan bagi guru.
\end{abstract}

\section{Kata Kunci : Komite Sekolah, Prestasi MI}

\section{Konteks Penelitian}

Dalam kehidupan sehari-hari, setiap orang pasti mengadakan hubungan atau interaksi dengan orang lain. Interaksi tersebut dapat berupa interaksi yang berlangsung dalam bidang sosial, ekonomi, politik, pendidikan dan sebagainya. Salah satu dari interaksi tersebut dapat berupa interaksi pendidikan. Interaksi pendidikan dapat berlangsung dengan siapa saja, baik di lingkungan keluarga, sekolah maupun masyarakat. Masyarakat adalah sekumpulan manusia yang secara relatif mandiri, yang hidup bersama-sama cukup lama, yang mendiami suatu wilayah tertentu, memiliki kebudayaan yang sama dan melakukan sebagian besar kegiatannya dalm kelompok tersebut.

Pendidikan merupakan bagian penting dari proses pembangunan nasional 
yang ikut menentukan pertumbuhan ekonomi suatu negara. Pendidikan juga merupakan investasi dalam pengembangan sumber daya manusia, dimana peningkatan kecakapan dan kemampuan diyakini sebagai faktor pendukung upaya manusia dalam mengarungi kehidupan yang penuh dengan ketidakpastian. Dalam kerangka inilah pendidikan diperlukan dan dipandang sebagai kebutuhan dasar bagi masyarakat Indonesia yang memiliki wilayah yang sangat luas.

Pendidikan menjadi hal yang sangat fundamental bagi kehidupan seseorang, dengan pendidikan yang baik maka akan baik pula pola pikir dan sikap seseorang. Pendidikan yang baik terbentuk dari pola dan sistem pendidikan yang baik pula. Pola dan sistem pendidikan yang baik terwujud dengan kurikulum yang baik.

Keberhasilan suatu lembaga pendidikan ditentukan oleh hubungan yang baik antara pihak sekolah dengan komite dan antara pihak sekolah dengan masyarakat. Komite sekolah adalah suatu lembaga mandiri dibentuk dan berperan dalam peningkatan mutu pelayanan dengan memberikan pertimbangan, arah dan dukungan tenaga, sarana dan prasarana serta pengawasan pada tingkat satuan pendidikan.

Kita harus menyadari bahwa masyarakat memiliki peranan yang sangat penting terhadap keberadaan, kelangsungan bahkan kemajuan lembaga pendidikan Islam. Setidaknya salah satu parameter penentu nasib lembaga pendidikan islam adalah masyarakat. Bila ada lembaga pendidikan Islam maju, hampir bisa dipastikan salah satu faktor keberhasilan tersebut adalah keterlibatan masyarakat yang maksimal. Begitu pula sebaliknya, bila ada lembaga pendidikan Islam yang bernasib memprihatinkan, salah satu penyebabnya bisa terjadi karena masyarakat enggan mendukung. Sikap masyarakat ini bisa jadi akibat baik secara internal dan eksternal. ${ }^{1}$

1 Mujamil Qomar (2007), Manajemen Pendidikan Islam, Erlangga, Bandung, hlm. 183
Kepercayaan masyarakat menjadi salah satu kunci kemajuan lembaga pendidikan Islam. Ketika masyarakat memiliki kepercayaan terhadap lembaga, mereka akan mendukung penuh bukan saja dengan memasukkan putra-putrinya ke dalam lembaga pendidikan tersebut, tetapi bahkan mempengaruhi orang lain untuk melakukan hal yang sama. Sebaliknya ketika masyarakat tidak percaya, mereka bukan hanya tidak mau memasukkan putraputrinya ke lembaga pendidikan tersebut, tetapi bahkan memprovokasi tetangga atau kawannya. Ini berarti masyarakat merupakan komponen strategis yang harus mendapat perhatian penuh oleh manager pendidikan Islam.

Penampilan fisik sekolah sangat mempengaruhi persepsi masyarakat tentang baik dan kurang baiknya suatu sekolah. Kompleks sekolah yang mempunyai gedung besar, lingkungan eksklusif, indah, bersih, dan terawat rapi cenderung dipersepsikan sebagai institusi pendidikan yang pengelolaannya baik dan berprestasi. Dampak dari persepsi ini, sekolah yang memiliki gedung yang megah dengan lingkungan yang eksklusif oleh masyarakat dinilai maju dan dijadikan sekolah favorit. ${ }^{2}$

Lembaga pendidikan khususnya sekolah, hendaknya tidak mengabaikan kegiatan hubungan dengan masyarakat. Kegiatan tersebut dikenal dengan hubungan masyarakat atau humas. Kegiatan humas sangat penting dilaksanakan sekolah karena selain sekolah berada di tengah-tengah lingkungan masyarakat, sekolah mengadakan hubungan masyarakat juga untuk menjalin kerjasama yang pedagogis dan sosiologis, yang tentu saja menguntungkan kedua belah pihak. Hubungan masyarakat merupakan fungsi manajemen yang diadakan untuk menilai dan menyimpulkan sikap publik, menyesuaikan kebijaksanaan dan prosedur instansi atau organisasi dengan kepentingan umum, serta menjalankan suatu program untuk

2 Imron Arifin (2008), Kepemimpinan Kepala Sekolah dalam Mengelola Sekolah, Aditya Media Publising, Yogyakarta, hlm. 282 
mendapatkan pengertian dan dukungan masyarakat. ${ }^{3}$

Masyarakat memiliki posisi ganda, yaitu sebagai obyek dan sebagai subyek yang keduanya memiliki makna fungsional bagi pengelolaan lembaga pendidikan Islam. Ketika lembaga pendidikan melakukan promosi penerimaan calon siswa baru, maka masyarakat merupakan obyek yang mutlak dibutuhkan. Sementara itu respon masyarakat terhadap promosi itu menempatkan mereka sebagai subyek yang memiliki kewenangan penuh untuk menerima atau menolaknya. Manajer lembaga pendidikan tidak berwenang memaksa sikap individu dari masyarakat. Posisi masyarakat sebagai subyek juga terjadi ketika mereka menjadi pengguna lulusan lulusan lembaga tersebut. Oleh karenanya, hubungan dengan masyarakat harus dikelola dengan baik. Kualitas Pendidikan adalah pelaksanaan pendidikan di suatu lembaga, sampai dimana pendidikan di lembaga tersebut telah mencapai suatu keberhasilan. Kualitas yang baik dapat tercapai manakala ada hubungan yang sinergis antara pihak sekolah dengan komite dan dengan masyarakat.

Kepala sekolah yang baik merupakan salah satu kunci untuk bisa menciptakan hubungan yang baik antara sekolah dan masyarakat secara efektif karena harus menaruh perhatian tentang apa yang terjadi pada peserta didik di sekolah dan apa yang dipikirkan orang tau tentang sekolah. Kepala sekolah dituntut untuk senantiasa berusaha membina dan meningkatkan hubungan kerja sama yang baik antara sekolah dan masyarakat guna mewujudkan sekolah yang efektif dan efisien.

Melalui hubungan yang harmonis tersebut diharapkan tercapai tujuan hubungan sekolah dengan masyarakat, yaitu terlaksananya proses pendidikan di sekolah secara produktif, efektif dan efisien sehingga menghasilkan lulusan sekolah yang produktif, dan berkualitas. Lulusan

3 Suryosubroto (2012), Hubungan Sekolah dengan Masyarakat, Rineka Cipta, Jakarta, hlm. 13

4 E Mulyasa (2006), Manajemen Berbasis Sekolah, Remaja Rosdakarya, Bandung, hlm. 52 yang berkualitas ini tampak dari penguasaan peserta didik terhadap ilmu pengetahuan, ketrampilan dan sikap, yang dapat dijadikan bekal untuk melanjutkan pendidikan pada jenjang berikutnya atau hidup di masyarakat sesuai dengan asas pendidikan seumur hidup. ${ }^{4}$

Berangkat dari masalah tersebut diatas, penulis tertarik untuk meneliti tentang "Upaya Komite Sekolah dalam Meningkatkan Prestasi Madrasah Ibtidaiyah Miftahul Huda Kaliboto Tarokan Kediri"

Berangkat dari latar belakang masalah di atas, maka permasalahan yang akan penulis angkat dalam penelitian ini adalah:

1. Keterlibatan komite Madrasah Ibtidaiyah Miftahul Huda Kaliboto Tarokan Kediri.

2. Upaya komite sekolah dalam meningkatkan prestasi Madrasah Ibtidaiyah Miftahul Huda Kaliboto Tarokan Kediri.

\section{Komite Sekolah}

Komite Sekolah/madrasah, sebagai lembaga mandiri, dibentuk dan berperan dalam peningkatan mutu pelayanan dengan memberikan pertimbangan, arahan, dan dukungan tenaga, sarana dan prasarana, serta pengawasan pendidikan pada tingkat satuan pendidikan. ${ }^{5}$

Ketika UU Nomor 20 Tahun 2003 belum diterbitkan, ketika itu Dewan Pendidikan dan Komite Sekolah masih menggunakan landasan hukum berupa Kepmendiknas dalam proses pembentukan dan pelaksanaannya, banyak pihak yang sangat meragukan eksistensi Komite Sekolah sebagai badan yang bisa melaksanakan pern dan tugasnya dengan baik. Dengan UU saja orang masih saja boleh meragukan keterlaksanaan Dewan Pendidikan dan Komite Sekolah dengan

\footnotetext{
5 Undang-Undang Sisdiknas (Sistem Pendidikan Nasional) UU RI No. 20 Th. 2003, Sinar Grafika, Jakarta, hlm. 37
} 
baik, apalagi hanya dengan menggunakan dasar hukum kepmendiknas. ${ }^{6}$

Dalam Peraturan Menteri

Pendidikan dan Kebudayaan Republik Indonesia Nomor 75 Tahun 2016 Tentang Komite Sekolah disebutkan dalam Pasal 1 ayat 2 disebutkan: Komite Sekolah adalah lembaga mandiri yang beranggotakan orangtua/wali peserta didik, komunitas sekolah, serta tokoh masyarakat yang peduli pendidikan.

Dewan Pendidikan dan Komite Sekolah merupakan amanat rakyat yang telah tertuang dalam UU Nomor 25 Tahun 2000 tentang Program Pembangunan Nasional (Propenas) 2000-2004. Amanat rakyat ini selaras dengan kebijakan otonomi daerah, yang telah memposisikan kabupaten/kota sebagai pemegang kewenangan dan tanggung jawab dalam penyelenggaraan pendidikan. Pelaksanaan pendidikan di daerah tidak hanya diserahkan kepada kabupaten/kota, melainkan juga dalam beberapa hal telah diberikan kepada satuan pendidikan, baik pada jalur pendidikan sekolah maupun luar sekolah. Dengan kata lain, keberhasilan dalam penyelenggaraan pendidikan tidak hanya menjadi tanggung jawab pemerintah pusat, melainkan juga pemerintah propinsi, kabupaten/kota, dan pihak sekolah, orang tua, dan masyarakat atau stakeholder pendidikan. Hal ini sesuai dengan konsep partisipasi berbasis masyarakat (community-based participation) dan manajemen berbasis sekolah (school-based management), yang kini tidak hanya menjadi wacana, tetapi telah mulai dilaksanakan di Indonesia.

Untuk melaksanakan amanat rakyat tersebut, pada tahun anggaran 2001 Pemerintah telah melaksanakan rintisan sosialisasi pembentukan Dewan Pendidikan dan Komite Sekolah di Propinsi Sumatera Barat, Bali, dan Jawa Timur masing-masing satu kabupaten/kota. Selain itu ada beberapa kabupaten/kota yang telah membentuk Dewan Pendidikan dan Komite Sekolah berdasarkan inisiatif sendiri.

6 Agus Haryanto, Suparlan, Yudistira (2008) Komite Sekolah Sejarah dan Prospeknya di Masa Depan, Hikayat Publishing, Yogyakarta, hlm. 76-77
Berdasarkan hasil sosialisasi tersebut, dapat disimpulkan bahwa keberadaan Dewan Pendidikan dan Komite Sekolah memang dipandang sangat strategis sebagai wahana untuk meningkatkan mutu pendidikan di Indonesia. Beberapa kalangan masyarakat yang diundang untuk memberikan masukan tentang pembentukan Dewan Pendidikan dan Komite Sekolah, pada umumnya sangat antusias dan mendukung sepenuhnya gagasan ini.

Sesuai dengan aspirasi berbagai kalangan masyarakat tersebut, maka proses pembentukan Dewan Pendidikan di tingkat kabupaten/kota dan Komite Sekolah di tingkat satuan pendidikan memerlukan program sosialisasi dengan perencanaan yang matang. Agar program sosialisasi dapat dilaksanakan dengan baik, diperlukan: (1) materi sosialisasi berupa Panduan Umum Dewan Pendidikan dan Komite Sekolah, (2) petugas sosialisasi, dan (3) koordinasi dengan pemerintah propinsi dan kabupaten/kota.

Komite Sekolah dapat dibentuk dengan dua alternatif kedudukan. Pertama, berkedudukan di satu sekolah yang bersangkutan. Artinya, Komite Sekolah ini dibentuk untuk sekolah bersangkutan saja. Kedua, dapat dibentuk di satu komplek persekolahan yang terdiri dari beberapa sekolah, baik jenjang maupun jenis sekolahnya. Di sekolah Indonesia di luar negeri, sebagai contoh, terdiri dari TK/RA, SD/MI. SMP/MTs, SMA/MA, dan SMK/MAK yang berlokasi dalam satu kompleks yang sama dan hanya dibentuk satu Komite Sekolah saja.

Kegiatan berhubungan dengan masyarakat atau sering disebut humas, pada hakikatnya adalah suatu kegiatan yang pasti dilakukan setiap lembaga, baik lembaga kedinasan, lembaga swasta, lembaga sosial, maupun lembaga ekonomi komersial. Hal itu terjadi karena dalam kehidupan ini manusia selain sebagai makhluk individu juga sebagai makhluk sosial atau makhluk bermasyarakat. Jadi, 
dimanapun manusia berada, ia selalu berhubungan dengan masyarakat, baik masyarakat sekitar maupun masyarakat luas. Hubungan dengan masyarakat dilakukan dengan tujuan memperoleh keuntungan dan kemudahan bagi kedua belah pihak. Oleh karena itu, apabila kegiatan humas dilaksanakan dengan baik, pasti menghasilkan suatu kerja sama (partnership) yang baik bagi keduanya.

Kegiatan humas yang dilaksanakan lembaga-lembaga pendidikan atau badanbadan penyelenggara pendidikan dimaksudkan untuk mengabdi pada kepentingan pendidikan. Kemudian kegiatan itu disebut humas pendidikan. Khusus di sekolah, kegiatan tersebut dinamakan publisitas sekolah.

Kegiatan humas pendidikan atau lebih konkrit hubungan sekolah dengan masyarakat memiliki latar belakang pemikiran yang tidak berbeda dengan kegiatan humas pada umumnya. Oleh karena itu, proses kegiatan dan asas penting dalam kehumasan perlu memperoleh perhatian semestinya apabila sekolah melakukan hubungan dengan masyarakat. ${ }^{7}$

Di dalam GBHN ditegaskan bahwa pendidikan adalah tanggung jawab bersama antara pemerintah, orang tua, dan masyarakat. Masyarakat terdiri atas kelompok-kelompok dari individu-individu yang berusaha menyelenggarakan pendidikan atau menbantu usaha-usaha pendidikan. Dalam masyarakat terdapat berbagai organisasi penyelenggara pendidikan, organisasi keagamaan, organisasi kepramukaan, organisasi politik, organisasi sosial, organisasi olahraga, atau organisasi kesenian yang bergerak dalam usaha pendidikan. Di dalam masyarakat juga terdapat individu-individu atau pribadipribadi yang bersimpti terhadap pendidikan di sekolah.

Sekolah menghendaki agar siswanya kelak menjadi manusia pembangun yang Pancasialis. Masyarakat juga menghendaki agar semua warga negara menjadi manusia pembangun yang pancasialis. Individu yang pancasialis

7 Suryosubroto (2012), Hubungan Sekolah dengan Masyarakat, PT Rineka Cipta, Jakarta, hlm. 12 diharapkan datang dari sekolah. Oleh karena itu, antara sekolah dan masyarakat harus mempunyai kesamaan tujuan.

Waktu belajar siswa di sekolah sangat terbatas, yaitu tujuh jam. Di luar sekolah mereka berada di rumah atau di lingkungan masyarakat. Waktu senggang $\mathrm{di}$ luar sekolah dapat dimanfaatkan untuk berbagai kegiatan atau organisasi, misalnya kegiatan kepramukaan, keolahragaan , kesenian, dan keagamaan. Selain itu, masyarakat juga dapat menyelenggarakan pendidikan yang bersifat spesialisasi, misalnya pendidikan keahlian. Alangkah baik jika program-program yang telah disusun dikonsultasikan terlebih dahulu dengan pihak sekolah tempat anggota masyarakat belajar.

BP3 adalah organisasi yang beranggotakan orang tua siswa atau anggota masyarakat yang mempunyai minat terhadap suatu sekolah. Biasanya, setiap sekolah memiliki satu organisasi BP3. Jadi, seorang anggota masyarakat dapat menjadi anggota BP3 di beberapa sekolah. Melalui BP3 diharapkan bantuan dan masyarakat datang, misalnya berupa uang, alat pendidikan, gedung, dan barang keperluan sekolah. Bantuan tersebut dapat diberikan langsung kepada pengurus BP3, untuk diteruskan kepada sekolah. ${ }^{8}$

Pembangunan dalam bidang pendidikan yang dilaksanakan oleh pemerintah bersama masyarakat merupakan upaya pengejawantahan salah satu citacita nasional, yaitu mencerdaskan kehidupan bangsa. Mencerdaskan kehidupan bangsa ini dapat dilakukan melalui jalur pendidikan, pendidikan merupakan kunci pembuka kearah kemajuan suatu bangsa, pendidikan yang maju tidak lepas dari kepemimpinan kepala sekolah.

Sekolah merupakan pelaku pembaharuan masyarakat. Kemampuan baca tulis hitung yang diberikan pada jenjang pendidikan dasar, sebagai misal, merupakan kemampuan dasar yang sangat penting untuk mendorong kelahiran masyarakat belajar. Seandainya sekolah tidak dapat membekali kemampuan dasar

8 Ibid., hlm. 64 
baca tulis hitung di kalangan warga masyarakat, sudah tentu masyarakat menjadi buta huruf. Lebih dari itu, kemungkinan masyarakat juga akan menjadi buta ilmu pengetahuan dan tehnologi. Lembaga pendidikan sekolah mulai dari jenjang pendidikan dasar, menengah, dan tinggi menjadi wahana pengembangan ilmu pengetahuan dan tehnologi.

Pada era globalisasi, hasil pembelajarn siswa, baik dari aspek akademis maupun nonakademis diharapkan dapat menghasilakan lulusan yang memiliki daya saing tinggi di arena internasional. Oleh karena itu, sekolah diharapakan memiliki wawasan keunggulan tertentu yang memiliki daya saing yang tinggi di arena pasar bebas. Dalam bidang ilmu murni, sekolah harus mampu menghasilkan lulusan yang berkompetensi unggul dalam bidang matematika, sains, dan teknologi. Dalam bidang komunikasi, sekolah juga harus mampu menghasilkan lulusan yang kompetensi dalam bahasa asing. Demikian juga dalam bidang-bidang yang lain, seperti moral, kepribadian, olahraga dan seni. Bahkan pada era tehnologi informasi sekolah juga dituntut untuk dapat menghasilkan lulusan yang melek komputer.

Untuk dapat menghasilkan lulusan yang diharapkan, maka pengelolaan sekolah tidak cukup dilakukan dengan polapola manajemen tradisional. Sekolah dewasa ini dikelola dengan manajemen terbuka dan melibatkan sinergi antara berbagai bidang keahlian seperti manajemen, keuangan, motivasi, pemasaran, di samping pakar dalam bidang pendidikan psikologi anak. Dari sinilah kemudian lembaga pendidikan sekolah berkembang dengan pesat menjadi ajang kegiatan bisnis yang tidak kecil nilai sosial ekonominya. Dalam kegiatan bisnis pendidikan ini, lahirlah lembaga yang bergerak dalam bidang pendidikan sekolah dan kursus. Lembaga lembaga pendidikan sekolah yang bertaraf internasional tumbuh menjamur di berbagai kota besar di banyak negara di dunia.
Dengan pendidikan sekolah, anakanak terpaksa mausk kelas yang sudah diatur dengan pola klasikal. Dengan model klasikal tersebut, anak-anak dipaksa harus mendengarkan ceramah dari snag guru dengan tidak ada atau sedikit memberikan kesempatan bertanya, duduk terpaku di dalam kelas dalam beberapa jam pelajaran, dan seterusnya sampai akhir pelajaran, kemudian pulang dari sekolah dengan tidak membawa bekal yang dapat mereka gunakan dalam kehidupan sehari-hari. Apa yang dipelajari di sekolah dinilai sering tidak terkait dengan kehidupan nyata dalam masyarakat.

Masyarakat memiliki harapan dan tuntutan yang lebih besar kepada sekolah. Sekolah diharapakan tidak hanya memberikan dogma-dogma atau hal-hal yang bersifat teoritis dan akademis, tetapi hal-hal yang dibutuhkan masyarakat, seperti sikap, kepribadian, dan ketrampilan, dan bekal kemampuan untuk hidup dalam masyarakat.

Di samping itu, sepatutnya sekolah juga tidak hanya memberikan pelayanan bagi anak-anak yang akan melanjutkan ke jenjang pendidikan yang lebih tinggi misalnya sampai ke perguruan tinggi, karena pada kenyataannya tidak semua siswa kita nanti sekolah sampai perguruan tinggi, mungkin berhenti pada tingkat SMP atau SMA. Oleh karena itu, pendidikan dasar harus dapat bertindak bijak, dengan menerapkan konsep pendidikan berbasis luas atau masyarakat, artinya pendidikan di sekolah tidak hanya membekali siswa kemampuan akademis yang diperlukan untuk meneruskan ke perguruan tinggi, tetapi yang lebih penting adalah memberikan bekal kecakapan hidup (life skill) yang diperlukan untuk dapat terjun ke masyarakat atau dunia kerja.

Pendidikan berbasis masyarakat
juga berarti pendidikan yang diselenggarakan dari, oleh, dan untuk msyarakat. Masyarakat ikut berperan dalam perencanaan, penganggaran, dan perumusan program dan kegiatan pendidikan, serta kompetensi lulusan yang diharapkan. Penyelenggaraan pendidikan tidak hanya menjadi tanggungjawab 
pemerintah, melainkan merupa-kan tanggung jawab bersama dengan masyarakat.

Pendidikan merupakan sebuah interaksi antara dua orang atau lebih, baik bersifat formal, non formal maupun informal. Proses pendidikan akan berlangsung selama masih ada kehidupan duniawi. Namun pendidikan yang seringkali mendapat reaksi dan perhatian serius dari pihak-pihak terkait adalah pendidikan formal karena diharapkan dapat menghasilkan peserta didik yang berkualitas melalui pendidikan yang berkualitas pula.

Untuk mendapatkan pendidikan yang berkualitas dibutuhkan beberapa input pendidikan. Input pendidikan adalah segala sesuatu yang harus tersedia karena dibutuhkan untuk berlangsungnya proses. Sesuatu yang berupa sumber daya dan perangkat lunak serta harapan-harapan sebagai pemandu bagi berlangsungnya proses.

Input pendidikan meliputi, input sumber daya, meliputi sumber daya manusia (kepala sekolah, guru, guru BP, karyawan, siswa) dan sumber daya lainnya (peralatan, perlengkapan, uang dan bahan). Input perangkat lunak, meliputi struktur organisasi sekolah, peraturan perundangundangan, deskripsi tugas, rencana dan program. Input harapa-harapan, berupa visi, misi, tujuan dan sasaran-sasaran yang dicapai oleh sekolah.

Pemimpin adalah bukan seorang sosok yang hanya dapat membuat visi dan misi, akan tetapi pemimpin adalah orangorang yang dapat mempengaruhi perilaku orang lain untuk tujuan mencapai tujuan. Mereka dapat mendukung kolega untuk mengubah perilakunya, mengambil pendekatan baru untuk bekerja dan membangun pola pikir baru. Dengan demikian pemimpin dituntut untuk dapat membawa koleganya untuk senantiasa bekerjasam dalam mencapai tujuan. ${ }^{9}$

Berdasarkan peran dan fungsi komite sekolah tersebut, maka pada tahap awal pembentukannya komite sekolah disambut dengan sangat positif oleh sebagian besar masyarakat, dengan harapan yang tinggi pula. Meskipun demikian, pada tahun-tahun pertama, harapan yang tinggi itu ternyata banyak yang pupus di tengah jalan. Penyebabnya antara lain karena pelaksanaan peran dan fungsi komite sekolah masih sangat variatif. Di satu pihak ada komite sekolah yang masih melanjutkan peran dan fungsi BP3 yang sering disebut sebagai "stempel" kepala sekolah. Artinya komite sekolah ini hanya mengekor apa yang diprogramkan oleh kepala sekolah. Komite sekolah tidak memiliki ide kreatif dan gagasan inovatif untuk meningkatkan hasil belajar siswa. Jadi program kepala sekolah itulah yang menjadi program komite sekolah. Sebaliknya ada pula komite sekolah yang sangat ditakuti oleh kepala sekolah. Kedudukan kepala sekolah sering menjadi incaran kritik dan pengawasan berlebihan oleh pihak komite sekolah. Apalagi kepala sekolah tersebut melaksanakan tugasnya secara tidak transparan, demokratis, dan akuntabel. Jika kepala sekolah jelas-jelas melakukan penyelewengan, maka komite sekolah ini tidak segan-segan lagi mengajukan rekomendasi kepada dinas pendidikan untuk mengganti kepala sekolah tersebut. Peran sebagai badan pengawasan lebih menonjol dibandingkan dengan yang lain. Bahkan ada peristiwa lucu, karena kepala sekolah ngantor di warung sebelah sekolah, gara-gara takut karena di kantornya sedang ada ketua komite sekolah.

Oleh karena itu, diharapkan komite sekolah bukan lagi sebagai "stempel" dan tidak juga sebagai "eksekutor" bagi kepala sekolah. Komite sekolah harusnya dapat menjadi wahan pemersatu antara keluarga, sekolah dan masyarakat.

Dinyatakan secara tegas, bahwa Komite Sekolah merupakan lembaga mandiri dan bersifat independen. Kedudukan komite sekolah tidaak dibawah kepala sekolah atau di bawah bayangbayang kekuasaan kepala sekolah. Kedudukan kepala sekolah sama sekali

${ }^{9}$ Intelektual Jurnal pendidikan Islam (2015), Program Pascasarjana IAIT Kediri, hlm. 70 
tidak sebagai "pembina" seperti kedudukan BP3 pada era sebelumnya. Independensi kedudukan dan peran tersebut mrnjadi terganggu, misalnya hanya karena salah satu sumber anggaran komite sekolah mungkin berasal dari Rencana Anggaran Penerimaan dan Belanja Sekolah (RAPBS). Dengan tersedianya anggaran dalam RAPBS tersebut, maka ada anggapan bahwa komite sekolah menjadi lembaga birokrasi yang berada di bawah kepala sekolah, bahkan di bawah Kepala dinas Pendidikan. Penyediaan anggaran komite sekolah dalam RAPBS tidak berarti anggaran itu bukan dari kepala sekolah, melainkan bersumber dari keluarga dan masyarakat. ${ }^{10}$

Untuk menjadi badan yang mandiri sebagai wadah peran serta orangtua dan masyarakat, komite sekolah kelihatannya harus menempuh perjalanan panjang. Menjadi wahana pemersatu pendidikan keluarga, sekolah, dan masyarakat juga bukan pekerjaan yang mudah semudah membalikkan telapak tangan. Menjadi tantangan bagi komite sekolah yang menjadi wadah pemersatu antara keluarga, sekolah dan masyarakat.

\section{Prestasi Sekolah}

Prestasi adalah hasil yang telah dicapai dari apa yang telah dilakukan oleh sekolah. Prestasi adalah bukti keberhasilan usha yang dapat dicapai, prestasi tidak dapat dicapai bila seseorang tidak melakukan kegiatan. Sekolah merupakan suatau sistem dimana pelaksanaan yang berorientasi pada kegiatan belajar mengajar dan pelaksanaan pengajaran yakni interaksi guru dengan murid, dalam rangka menyampaikan bahan pelajaran pada siswa dan untuk mencapai tujuan pengajaran.

Jadi prestasi sekolah dapat diartikan sebagai penilaian hasil belajar dari proses kegiatan belajar mengajar yang dinyatakan dalam bentuk simbol, angka, huruf maupun kalimat yang dapat mencerminkan hasil yang sudah dicapai oleh setiap siswa dalam periode selama masih dalam bangku sekolah sehingga dapat membawa perubahan baik dari segi kognitif, afektif, dan psikomotorik yang dinyatakan dalam angka menurut kemampuan siswa dalam mengerjakan tes pelajaran. Prestasi sekolah dalam kehidupan manusia pada tingkat dan jenis tertentu dapat memberikan kepuasan pada bangku sekolah.

Ciri-ciri siswa berbakat dalam pencapaian prestasi sekolah dapat di indikatorkan sebagai berikut: memiliki ciri tanggung jawab terhadap tugas seperti tekun menghadapi tugas, ulet menghadapi kesulitan, mampu bekerja sendiri tanpa bantuan orang lain, ingin berprestasi sebaik mungkin, senang dan rajin belajar, penuh semnagt dan tidak bosan dengan tugas rutin. Memiliki ciri belajara antara lain mudah menangkap pelajaran, mempunyai ingatan baik, perbendaharaan kata yang luas, penalaran tajam, berfikir tajam, berfikir kritis, logis sering membaca buku yang bermutu dan mempunyai rasa ingin tahu yang bersifat intelektual. Memiliki kreatifitas antara lain bersifat ingin tahu, sering mengajukan pertanyaan yang baik, memberikan gagasan dan usul atas banyak permasalahan, tidak mudah terpengaruh orang lain dan mampu mengajukan pandangan yang berlainan dengan orang lain. Memiliki sciri-ciri kepribadian yang disenangi oleh orang lain, dipilih menjadi pemimpin, dapat bekerja sama, dapat mempengaruhi orang lain, banyak inisiatif dan percaya diri sendiri.

Faktor-faktor yang mempengaruhi prestasi sekolah terlaksananya suatu pendidikan yang mengorientasikan pada prestasi sekolah siswa dengan baik apabila dalam pelaksanaannya senantiasa berpegang teguh pada prinsip-prinsip yang telah diberlakukan.

$$
\text { Dalam rangka mengukur }
$$

keberhasilan belajar peserta didik itu, pengukurannya dilakukan secara tidak langsung. Seorang pendidik yang ingin menentukan manakah diantara para peserta didik yang tergolong lebih pandai ketimbang peserta didik lainnya. Dalam

10 Agus Haryanto, Suparlan, Yudistira (2008) Komite Sekolah Sejarah dan Prospeknya di Masa Depan, Hikayat Publishing, Yogyakarta, hlm. 84-85 
rangka menilai keberhasilan belajar siswa pada umumnya menggunakan ukuran yang bersifat kuantitatif sekaligus pendidikan ketrampilan juga berpengaruh penting dan sebagai dasar latihan yang dapat membentuk ketrampilan kerja. Yang dapat diekspresikan melalui cipta, rasa dan karsa secara kreatif dan produktif.

Prestasi sekolah sama dengan mutu yang telah dicapai oleh sebuah lembaga pendidikan. Pengertian mutu memiliki konotasi yang bermacam-macam tergantung orang yang memakainya. Kata mutu diambil dari bahasa latin "Qualis" yang artinya what kind of (tergantung dengan kata apa yang mengikutinya). Pengertian mutu sendiri menurut Deming ialah kesesuaian dengan kebutuhan. Sedangkan menurut Juran, mutu ialah kecocokan dengan kebutuhan. Sallis mengemukakan bahwa mutu adalah konsep yang absolut dan relatif. Mutu yang absolut adalah mutu yang mempunyai idealisme tinggi dan berstandar tinggi yang harus dipenuhi, dengan sifat produk bergengsi yang tinggi. Sedangkan mutu relatif adalah sebuah alat yang sudah ditetapkan dan harus memenuhi standar yang telah dibuat.

\section{Madrasah dan Sekolah Berprestasi}

Sekolah yang berprestasi seringkali disebut sebagai sekolah efektif yaitu sekolah yang tinggi skor tes prestasinya dalam membaca, menulis, dan matematik sejauh yang bisa dicapai seumumnya murid-murid. Sekolah efektif tidak sematamata ditentukan oleh performansi akademik, melainkan juga mencakup sejumlah tujuan sekolah yang bersifat non akademik. Steenbrink menyatakan bahwa sekolah atau madrasah yang berprestasi seringkali diasumsikan masyarakat di Indonesia sebagai sekolah atau madrasah yang favorit di tengah-tengah masyarakat.

Sekolah berprestasi di negaranegara maju seringkali disebut sekolah yang baik (good schools) atau sekolah yang telah terperbaiki (improved schools), atau sekolah sukses (successful schools) atau sekolah yang efektif (effective schools), dan bahkan pada kondisi tertentu disebut sebagai sekolah unggul (excellent schools).
Penyebutan berbagai istilah ini pada dasarnya dimaksudkan memiliki karakteristik "baik" (good schools) yang dibedakan dengan sekolah yang umum dan kondisinya "buruk" atau "belum baik" (poor schools) dalam prestasi akademik maupun non akademiknya. Para ahli manajemen pendidikan seringkali mengukur sekolah yang baik atau sekolah yang efektif dikaitkan dengan the quality of education. Ada kecenderungan di masyarakat bahwa sekolah yang terkenal dan merupakan kesayangan masyarakat (favorite) selalu menjadi pilihan untuk menyekolahkan anak-anaknya. Namun demikian masyarakat di Indonesia mengasumsikan eksistensi sekolah favorit identik dengan sekolah unggul, yaitu sekolah mewah (exclusive schools) atau sekolah yang mahal atau elite schools yang hanya terjangkau oleh elit ekonomi kelas atas. Sementara itu menurut Suryadi dan Tilaar indikasi atas sekolah yang memiliki kualitas pendidikan dapat dilihat dari besarnya partisipasi sekolah, efisiensi internal, prestasi belajat kognitif, dan prestasi belajar efektif.

Penelitian sekolah yang efektif telah banyak dilakukan oleh para ahli manajemen pendidikan di negara-negara maju dan menjadi populer dewasa ini. Hasil-hasil penelitian yang telah dipublikasikan dan literatur yang membahas masalah tersebut juga mulai bermunculan. Namun hasil-hasil penelitian tersebut memperoleh kritik dari ahli manajemen pendidikan yang lain, terutama pada landasan teoritik, teknik pengukuran, maupun analisis datanya. Salah satu kelemahan dari penelitian sekolah yang baik atau efektif terletak pada kriteria pengukurannya yang cenderung dibatasi pada prestasi akademik murid, melalui tes prestasi terstandar atau hasil tes ketrampilan dasar di sekolah dasar.

Menurut Lipsitz meneliti sekolah yang baik secara artikulatif amatlah sulit, sebab kriteria kebaikan (goodness) menyangkut banyak hal. Sekolah yang baik atau efektif seringkali ditentukan oleh: (1) kualitas lulusan yang diakui institusi lain; tes skor murid diatas rata-rata kelompok murid lain yang sejenjang; guru dan muridmuridnya sama-sama bekerja keras untuk 
mencapai sukses; para murid puas dengan sekolahnya; jumlah murid yang dirujuk untuk layanan kesehatan mental rendah dibanding sekolah lain; para murid memenangkan lomba-lomba olag raga dan kegiatan ekstra lainnya; banayk murid yang berstudi bahasa asing; seni dan fisik; (2) para guru merencanakan pembelajaran secara memadai; anggota guru cukup memadai bagi murid; anggota guru bekerjasama, membagi ide, dan saling membantu di antara mereka; pergantian guru rendah; konflik guru rendah; (3) sekolah mempunyai perayaan hari besar nasional dan keagamaan; program kegiatan ekstrakurikuler yang menarik bagi murid; moral lembaga tinggi; dan (4) orang tua menerima hasil studi anaknya dengan baik, para orangtua mempunyai pilihan untuk mengirimkan anaknya pada sekolah favorit dibanding sekolah lainnya. ${ }^{11}$

Definisi pendidikan menurut undang-undang RI Nomor 20 tahun 2003 tentang Sistem Pendidikan Nasional atau Sisdiknas, pasal 1 ( ayat 1 dan 4), bahwa "pendidikan adalah usaha sadar dan terencana untuk mewujudkan suasana belajar dan proses pembelajaran agar peserta didik secara aktif mengembangkan potensi dirinya untuk memiliki kekuatan spiritual keagamaan, akhlak mulia, pengendalian diri, kecerdasan, keperibadian, serta keterampilan yang diperlukan untuk dirinya, masyarakat, bangsa dan juga negara."

Sedangkan menurut Husaini Usman, bahwa "peserta didik adalah anggota masyarakat yang berusaha mengembangkan potensi diri melalui proses pembelajaran yang tersedia pada jenjang, jalur dan jenis pendidikan.

Mutu di bidang pendidikan meliputi 4 mutu: input, proses, output dan outcome, yaitu :

a. Input pendidikan dinyatakan bermutu apabila telah berproses

b. Proses pendidikan bermutu jika mampu menciptakan suasana yang aktif, kreatif dan juga menyenangkan.

11 Imron Arifin (2008) Kepemimpinan kepala Sekolah mengelola Sekolah Berprestasi, Aditya Media Publishing, Yogyakarta, hlm. 40-41 c. Output dinyatakan bermutu jika hasil belajar dalam bidang akademik dan non akademik siswa tinggi.

d. Outcome dinyatakan bermutu apabila lulusan cepat terserap di dunia kerja, gaji yang wajar, dan semua pihak mengakui kehebatan lulusannya dan merasa puas.

Mutu dalam konteks manajemen mutu terpadu atau Total Quality Management (MTQ) bukan hanya satu gagasan, tetapi suatu filosofi dan metodelogi untuk membantu lembaga dalam mengelola perubahan secara sistematik dan totalitas, melalui suatu perubahan visi, misi, nilai serta tujuan. Di dalam dunia pendidikan untuk menilai mutu lulusan suatu sekolah dilihat dari kesesuaian dalam kemampuan yang dimilikinya dengan tujuan yang telah ditetapkan di dalam kurikulum.

Secara umum kualitas atau mutu adalah gambaran dan karakteristik menyeluruh dari barang atau jasa yang menunjukkan kemampuannya dalam memuaskan kebutuhan yang diharapkan atau tersirat.

Goesth dan Davis yang dikutip Tjiptono, mengemukakan bahwa kualitas diartikan sebagai suatu kondisi dinamis dimana yang berhubungan dengan produk, jasa, manusia proses dan lingkungan yang memenuhi atau melebihi harapan. Soekidjo Notoatmodjo menambahkan bahwa pendidikan secara umum adalah segala upaya yang direncanakan untuk mempengaruhi orang lain baik individu, kelompok, atau masyarakat sehingga mereka melakukan apa yang diharapkan oleh pelaku pendidikan. Lebih jauh, Hoy et al menjelaskan bahwa kualitas pendidikan adalah hasil penilaian terhadap proses pendidikan dengan harapan yang tinggi untuk dicapai dari upaya pengembangan bakat-bakat para pelanggan pendidikan melalui proses pendidikan. Demikian kualitas pendidikan merupakan suatu hal yang penting dalam proses pendidikan. Oleh karena itu perbaikan proses pendidikan merupakan salah satu upaya 
untuk mencapai keunggulan dalam penyelenggaraan pendidikan. Sedangkan menurut Ace Suryadi dan H.A.R Tilaar, kualitas pendidikan merupakan kemampuan lembaga pendidikan dalam mendayagunakan sumber-sumber pendidikan untuk meningkatkan kemampuan belajar seoptimal mungkin.

Kualitas pendidikan diterapkan dengan menjadikan pendidikan menjadi terarah kepada klien (client oriented) yang artinya menjadikan peserta didik sebagai prioritas utama dengan berusaha memberikan hasil pendidikan yang optimal dan menjalin kelangsungan peningkatan sumber daya manusia serta hasil pendidikan, menerapkan proses kontrol yang ketat, menjamin adanya sistem pelayanan yang baik dan meningkatkan keterlibatan pribadi dalam pendidikan.

Dari uraian penjelasan diatas dapat disimpulkan bahwa kualitas itu menunjuk pada pengertian pemenuhan standar atau persyaratan pendidikan. Kualitas pendidikan juga mempunyai pengertian sebagai upaya untuk melakukan perbaikan dan penyempurnaan secara terus menerus dalam pemenuhan kebutuhan pendidikan sehingga dapat tercapainya kesesuaian tujuan yang diharapkan. ${ }^{12}$

Sekolah dikatakan sukses apabila mampu melibatkan masyarakat untuk memberikan dukungan yang sehat, disamping itu keberadaan masyarakat merupakan sumber nilai yang memberikan arah normatif kepada pendidik. Pentingnya tercipta jalinan hubungan dan dukungan masyarakat pada sekolah memberikan reaksi positif terhadap dua informasi yang diberikan sekolah, yaitu laporan berkala yang memerinci program sekolah dan kegiatan extrakurikuler, dan pengumuman bahwa murid-murid sedang mengalami kesulitan dan memerlukan bantuan. Pelibatan orangtua sangat penting untuk keberhasilan program-program pendidikan

12 Mulyasa (2003), Manajemen Berbasis Sekolah ; Konsep, Strategi dan Implementasi, Remaja Rosdakarya, Bandung, hlm 212

13 Suryosubroto (2012), Hubungan Sekolah dengan Masyarakat, PT Rineka Cipta, Jakarta, hlm. 73 anak, terutama pada peningkatan prestasi murid, perbaikan perilaku, penurunan absensi murid dan pemupukan sikap positif murid pada sekolah. ${ }^{13}$

Keberhasilan

manajemen kelembagaan dan pembelajaran dalam pendidikan Islam, secara hakiki ditentukan atau bergantung pada kualitas sumber daya manusianya. Oleh karena disebelah pentingnya elemen lain seperti gedung, sarana pembelajaran, serta dana atau sumber pembiayaan, yang paling menentukan adalah unsur manusia, sebagai pemilik, pelaku, pengendali, dan pemrakarsa langkah pemanfaatannya guna mencapai tujuan yang diinginkan. Sumber daya manusia sebagai unsur pelaksana bagi keberhasilan manajemen lembaga dan aktifitas pendidikan Islam, dalam realitas banyak sekali ragamnya. ${ }^{14}$

Mutu atau kualitas bamyak dibicarakan orang, kelompok, organisasi, maupun suatu lembaga. Bagi setiap institusi, mutu merupakan hal utama yang harus selalu ditingkatkan. Dalam kehidupan sehari-hari biasanya orang yang memiliki keinginan untuk mendapatkan sesuatu yang bermutu. Oleh karena itu, Deming mendefinisikan mutu sebagai kesesuaian dengan kebutuhan pasar atau konsumen. Perusahaan yang bermutu adalah perusahaan yang menguasai pangsa pasar karena hasil produksinya sesuai dengan kebutuhan konsumen sehingga menimbulkan kepuasaan bagi konsumen. Jika konsumen merasa puas, mereka akan setia dalam membeli produk perusahaan tersebut baik berupa barang atau jasa. ${ }^{15}$

Keberadaan pemimpin dalam lembaga pendidikan Islam dirasakan penting sekali, bahkan mencapai tingkat urgen. Pemimpin merupakan subyek yang paling diharapkan banyak orang, khususnya para bawahan dan/atau masyarakat, agar mampu mendorong dan mengantarkan kemajuan lembaga pendidikan Islam. Setiap terjadi perguliran

14 Imam Bawani (2016), Metodologi Penelitian Pendidikan Islam, Kazanah Ilmu, Sidoarjo, hlm.304

15 Nurul Hidayah (2016) Kepemimpinan Visioner Kepala Sekolah Dalam Meningkatkan Mutu Pendidikan, Ar-Ruzz Media, Yogyakarta, hlm. 125 
suksesi kepemimpinan dalam suatu lembaga pendidikan Islam, selalu muncul harapan-harapan besar bahwa melalui kehadiran pemimpin yang baru dengan pola kepemimpinan yang baru mampu membawa kemajuan. Namun harapan itu tidak selalu terwujudkan. Kadang-kadang yang terjadi justru sebaliknya. Kehadiran pemimpin baru ternyata tidak mampu mempertahankan prestasi kemajuan sebelumnya, apalagi meningkatkan kemajuan sehingga yang terjadi justru kemerosotan terus-menerus.

Kondisi ini sangat mungkin terjadi dalam lembaga pendidikan Islam. Kondisi ini terkait dengan kewenangan dan kemampuan. Dari perspektif kewenangan, pemimpin memiliki kesempatan seluasluasnya untuk melakukan inovasi-inovasi, gebrakan-gebrakan, dan terobosanterobosan baru dalam merealisasikan kemajuan lembaga yang sedang dikendalikannya. Karena, pemimpin diberi mandat untuk melakukan pembaharuanpembaharuan konstruktif terhadap lembaga tersebut.

Ketika lembaga pendidikan Islam mendapatkan pemimpin yang andal dan memiliki kewenangan penuh dalam berkreasi memajukan lembaganya, maka lembaga pendidikan Islam tersebut cepat berhasil mencapai kemajuan sesuai dengan harapan berbagai kalangan. Jika kondisi ini yang terjadi, lembaga pendidikan Islam tersebut mendapat berkah, yakni berkah pemimpin yang andal dengan kepemimpinannya yang efektif mengukir prestasi kemajuan. Suatu model suatu kepemimpinan yang senantiasa berusaha digali dan dirintis keberadaannya baik dengan mendatangkan pemimpin dari luar maupun mengkader tenaga-tenaga profesional dari dalam lembaga pendidikan Islam itu sendiri. Hanya saja lebih utama jika kehadiran pemimpin yang andal itu dihasilkan dari upaya pengakaderan dari dalam, sebagai wujud keberhasilan pemimpin sebelumnya. ${ }^{16}$

\section{Metode Penelitian}

Penelitian ini menggunakan pendekatan kualitatif, kemudian penggalian datanya menggunakan metode obervasi, interview, dan dokumentasi. Sementara analisis datanya menggunakan analisis kualitatif dari Miles dan Hubberman, dengan tiga tahapan, yakni 1) reduksi data (data reduction), 2) penyajian data (data displays dan 3) penarikan kesimpulan/ verifikasi

(conclusion drawing/veriffication). Reduksi data berlangsung terus menerus selama penelitian berlangsung bahkan sebelum data benar-benar terkumpul sudah mengantisipasi akan adanya reduksi data sudah tampak sewaktu memutuskan kerangka konseptual, wilayah penelitian, permasalahan penelitian, dan penentuan metode pengumpulan data.

Yang terakhir kegiatan analisis pada tahap ketiga adalah menarik kesimpulan dan verifikasi. Sejak pengumpulan data peneliti berusaha mencari makna atau arti dari simbol-simbol, mencatat, keteraturan pola, penjelasan-penjelasan, dan alur sebab akibat yang terjadi. Dari kegiatan ini dibuat simpulan-simpulan yang sifatnya masih terbuka, umum, kemudian menuju ke yang spesifik/rinci. Kesimpulan final diharapkan dapat diperoleh setelah pengumpulan data selesai.

Adapun tempat penelitian ini bertempat di MI Miftahul Huda Kaliboto Kediri.

\section{Hasil Penelitian}

Dari paparan diatas bahwa komunikasi yang baik dan dedikasi pada pendidikan merupakan modal awal dalam membangun sebuah lembaga pendidikan yang berkualitas serta sesuai dengan tujuan pembelajaran yang diinginkan. Setiap wali murid menginginkan pendidikan yang terbaik bagi putra-putrinya, setiap sekolah ingin memberikan pelayanan pendidikan yang berkualitas. Pada dasarnya setiap lembaga mempunyai keterbatasan baik pemikiran maupun pendanaan, oleh sebab itulah pentingnya sebuah komunikasi untuk menjembatani kepentingan wali murid dan lembaga pendidikan agar apa yang menjadi 
tujuan bersama dapat terwujud salah satunya meningkatnya prestasi belajar peserta didik.

\section{Keterlibatan komite Madrasah Ibtidaiyah Miftahul Huda Kaliboto Tarokan Kediri.}

Keterlibatan komite sekolah Madrasah Ibtidaiyah Miftahul Huda Kaliboto Tarokan Kediri dalam beberapa hal yaitu:

a. Mendukung penuh visi sekolah agar mudah tercapai, dengan cara mengadakan pertemuan rutin dengan wali murid dan tokoh masyarakat, mengadakan lomba TK/RA se-kecamatan Tarokan, mengadakan pengajian umum dengan masyarakat di lingkungan sekolah dua tahun sekali. Sesuai dengan pendapat Agus Haryanto, Suparlan dalam buku Komite Sekolah Sejarah dan prospeknya di masa depan yang menyatakan bahwa: tujuan pembentukan komite sekolah adalah meningkatkan tanggungjawab dan peran serta masyarakat dalam penyelenggaraan pendidikan di satuan pendidikan, menciptakan suasana dan kondisi transparan, akuntabel, dan demokratis dalam penyelenggaraan dan pelayanan pendidikan yang bermutu di satuan pendidikan.

b. Memberikan pertimbangan dalam pelaksanaan program sekolah tentang kriteria sarana prasarana sekolah, kerjasama sekolah dengan masyarakat untuk kemajuan dan pengembangan sekolah dalam rangka peningkatan prestasi sekolah serta meningkatkan kepercayaan masyarakat. Sesuai dengan pendapat Agus Haryanto bahwa peran komite sekolah adalah sebagai lembaga pemberi pertimbangan (advisory agency), badan yang memberikan pertimbangan kepada sekolah atau yayasan. Idealnya, sekolah dan yayasan pendidikan yang meminta pertimbangan kepada komite sekolah dalam merumuskan kebijakan, program dan kegiatan sekolah, termasuk juga dalam merumuskan visi, misi dan tujuan sekolah. Ada visi, misi dan tujuan sekolah yang harus dirumuskan bersama dengan komite sekolah, seperti program unggulan apa saja yang ingin diterapkan oleh sekolah.

\section{Upaya komite sekolah dalam meningkatkan prestasi Madrasah Ibtidaiyah Miftahul Huda Kaliboto Tarokan Kediri.}

a. Mengadakan pertemuan rutin dengan wali murid satu semester sekali dan pengajian. Sekolah dituntut untuk senantiasa berusaha membina dan meningkatkan hubungan kerjasama yang baik antara sekolah dan masyarakat guna mewujudkan sekolah yang efektif dan efisien. Menurut Suryosubroto dalam buku Hubungan sekolah dengan masyarakat disebutkan bahwa: kerjasama yang erat antara sekolah dengan berbagai pihak yang ada di masyarakat dan mereka merasa ikut bertanggung jawab atas suksesnya pendidikan di sekolah.

b. Menggalang dana dan sumber daya pendidikan lainnya dari masyarakat dan para donatur

Dengan adanya dana yang cukup maka sekolah dapat meningkatkan pembangunan sarana prasarana yang memadai dan lengkap guna kelancaran program sekolah dan juga kegiatan pembelajaran dapat berjalan lancar dan efektif. Sesuai dengan pendapat Agus Suprayoga bahwa komite sekolah memiliki peran sebagai supprorting agency, badan yang memberikan dukungan berupa dana, tenaga dan pikiran dalam rangka penyelenggaraan dan peningkatan pendidikan.

c. Mengawasi dalam pelaksanaan kebijakan-kebijakan sekolah, antara lain:

1) Rekrutmen tenaga pendidik, 2). Proses penerimaan siswa baru, 3). Pembangunan ruang kelas baru dan sarana prasarana sekolah, 4). Menindaklanjuti keluhan, saran, kritik, dan aspirasi dari peserta didik, orangtua, dan masyarakat atas kinerja sekolah untuk peningkatan prestasi sekolah.

Sesuai dengan pendapat Agus Suprayoga Komite sebagai lembaga pengontrol (controlling agency), badan yang melaksanakan pengawasan sosial kepada sosial. Pengawasan sosial yang dilakukan lebih memiliki imploikasi sosial, dan lebih dilaksanakan secara preventif, yaitu dalam 
rekrutmen tenaga pendidik harus sesuai/linear antara kebutuhan dengan kualifikasi tenaga pendidik, proses penerimaan siswa baru sesuai kemampuan jumlah tenaga pendidik dengan ruang kelas yang ada, pembangunan ruang kelas baru dan sarana prasarana sesuai kemampuan keuangan. Serta menindaklanjuti keluhan, saran, kritik, dan aspirasi dari peserta didik, orangtua, dan masyarakat atas kinerja sekolah untuk peningkatan prestasi sekolah. Menurut Imron Arifin dalam buku kepemimpinan kepala sekolah mengelola sekolah berprestasi, disebutkan bahwa mutu di bidang pendidikan meliputi 4 mutu: input, proses, output, dan outcome, yaitu:

1). Input pendidikan dinyatakan bermutu apabila telah berproses 2). Proses pendidikan bermutu jika mampu menciptakan suasana yang aktif, kreatif dan juga menyenangkan, 3). Output dinyatakan bermutu jika hasil belajar dalam bidang akademik dan non akademik siswa tinggi, 4). Outcome dinyatakan bermutu apabila lulusan cepat terserap di dunia kerja, gaji yang wajar, dan semua pihak mengakui kehebatan lulusannya dan merasa puas.

Pengawasan yang dilakukan komite sekolah dalam rangka peningkatan prestasi sekolah dan mutu pendidikan di Madrasah Ibtidaiyah Miftahul Huda dapat tercapai sesuai dengan visi dan misi sekolah.

\section{Kesimpulan}

$\begin{array}{rrr}\text { Keterlibatan } & \text { komite sekolah } \\ \text { Madrasah Ibtidaiyah } & \text { Miftahul Huda }\end{array}$ Kaliboto Tarokan Kediri dalam beberapa hal yaitu mendukung penuh visi sekolah dengan cara: Silaturrahim dengan menghadirkan orangtua siswa, pengurus yayasan, pengurus komite sekolah dan tokoh-tokoh masyarakat, mengadakan lomba TK dan RA se-Kecamatan Tarokan, Mengadakan pengajian umum bersama masyarakat di lingkungan Madrasah Ibtidaiyah setiap 2 tahun sekali. Memberikan pertimbangan dalam pelaksanaan program sekolah tentang kriteria sarana prasarana sekolah, kerjasama sekolah dengan masyarakat untuk kemajuan dan pengembangan sekolah dalam rangka peningkatan prestasi sekolah serta meningkatkan kepercayaan masyarakat.

Sementara upaya komite sekolah dalam meningkatkan prestasi Madrasah Ibtidaiyah Miftahul Huda Kaliboto Tarokan Kediri, mengadakan pertemuan rutin dengan wali murid satu semester sekali dan pengajian. Menggalang dana dan sumber daya pendidikan lainnya dari masyarakat dan para donatur. Mengawasi dalam pelaksanaan kebijakan-kebijakan sekolah, antara lain: rekrutmen tenaga pendidik, proses penerimaan siswa baru, pembangunan ruang kelas baru dan sarana prasarana sekolah, menindaklanjuti keluhan, saran, kritik, dan aspirasi dari peserta didik, orangtua, dan masyarakat atas kinerja sekolah unk peningkatan prestasi sekolah. 


\section{Daftar Pustaka}

Agus Haryanto, Suparlan, Yudistira. (2008) Komite Sekolah Sejarah dan Prospeknya di Masa Depan. Hikayat Publishing, Yogyakarta.

Ahmadi Abu, Ahmad Rohani. (1991) Pedoman Administrasi Pendidikan Sekolah. Bumi Aksara, Jakarta. Arief Furkhon. (1999) Pengantar Metodelogi Penelitian Kualitatif. Usaha Nasional, Surabaya.Arifin Imron. (1996) Penelitian Kualitatif Dalam Ilmu-Ilmu Sosial Dan Keagamaan. Kalimashara Pers, Malang.

Arifin Imron. (2008) Kepemimpinan Kepala Sekolah dalam Mengelola Sekolah Berprestasi. Aditya Media, Yogyakarta.Arikunto Suharsimi. (1998) Prosedur Penelitian Suatu Pendekatan Praktik. Rineka Cipta, Jakarta.

Bawani Imam. (2016) Metodologi Penelitian Pendidikan Islam. Khazanah Ilmu, sidoarjo.

Departemen Agama Republik Indonesia (2002) Al Quran dan Terjemahnya. AlHidayah, Surabaya.

E. Mulayasa. (2002) Manajemen Berbasis Sekolah. Remaja Rosdakarya, Bandung.

Hadi Sutrisno. (1987) Metodologi Research. Andi Offset, Yogyakarta.

Hamalik Oemar. (2009) Proses Belajar mengajar. Bumi Aksara, Jakarta.

Hasbullah. (2006) Otonomi Pendidikan. PT Grafindo, Jakarta.

Hidayah Nurul (2016) Kepemimpinan Visioner Kepala Sekolah Dalam Meningkatkan Mutu Pendidikan. ArRuzz Media, Yogyakarta.
Institut Agama Islam Tribakti (IAIT) Kediri (2015) Intelektual Jurnal Pendidikan Islam, Program Pascasarjana

Moleong J Lexy. (2003) Metode Penelitian Kualitatif. Remaja Rosdakarya, Bandung.

Muhajir Noer. (1996) Metode Penelitian Kualitatif. Rake Sarikin, Yogyakarta.

Mulyasa. (2006) Manajemen Berbasis Sekolah. Remaja Rosdakarya, Bandung.

Peraturan Menteri Pendidikan dan Kebudayaan Republik Indonesia Nomor 75 Tahun 2016 Tentang Komite Madrasah

Purwanto Ngalim M. (1998) Psikologi Pendidikan. Remaja Rosdakarya, Bandung.

Qomar Mujamil. (2007) Manajemen Pendidikan Islam. Erlangga, Malang.

Sanjaya Wina. (2008) Strategi Pembelajaran Berorientasi Standar Proses Pendidikan, Kencana Prenada Media Group, Jakarta.

Sudjana Nana, Ibrahim. (2010) Penelitian dan Penilaian Pendidikan. Sinar Baru algesindo, Bandung.

Sugiyono. (2015) Memahami Penelitian Kualitatif. Alfabeta, Bandung.

Suharsimi Arikunto. (1996) Prosedur Penelitian: Suatu Pendekatan Praktek. Rineka Cipta, Jakarta.

Suryosubroto. (2012) Hubungan Sekolah Dengan Masyarakat. Rineka Cipta, Jakarta.

Susilo Suko. (2013) Dasar-dasar Psikologi Sosial. Jenggala Putra Utama, Surabaya.

Sutrisno Hadi. (1987) Metodologi Research. Andi Afset. Yogyakarta. 
Jurnal Dendidikan dan Studi Keislaman

Sutrisno Hadi. (1995) Metode Penelitian, Jilid II. Yayasan Penerbit Fak. Psikologi UGM, Yogyakarta.

Suprayogo Imam. (2001) Metode Penelitian Sosial Agama. PT. Remaja Rosdakarya, Bandung.

Syaiful Bahri Djamarah. (1994) Prestasi Belajar dan Kompetensi Guru. Usaha Nasional, Surabaya.

Undang-Undang Sisdiknas (Sistem Pendidikan Nasional) No. 20 Th. 2003, Sinar Grafika, Jakarta. 